UDK 78.01:004.4

Nico Schüler

School of Music, Texas State University

Fakulteta za glasho, Dř̌avna univerza v Texasu

\title{
Reflections on the History of Computer- Assisted Music Analysis I: Predecessors and the Beginnings
}

\section{Razmišljanje o zgodovini računalniške analize glasbe I: predhodniki in začetki}

Ključne besede: računalniška analiza glaslxe, informacijska teorija, razvoj zgodnjih računalnikov

POVZETEK

Gre za pruega v vrsti člankov, ki obravnavajo zgodovino računalniške analize glasbe. Prvi se ukvarja $\mathrm{s}$ filozofskimi osnovami računalniškc analize glasbe, to je $\mathrm{z}$ aplikacijo informacijske teorije $\mathrm{v}$ estetiki, kakor tudi $\mathrm{z}$ značilno uporabo statističnih in informacijsko-teoretičnih meritev na področju glasbene analize ter $z$ drugimi računalniškimi pristopi $\mathrm{h}$ glasbeni analizi, ki niso vključevali uporabo elektronskih računalnikov. Večinoma gre za tiste pristope, ki so predstavljali neposredne vzorce računalniškin aplikacijam. Na koncu daje članek kratek zgodovinski pregled zgodnjih računalnikov in povzema najbolj zgodnjo uporabo računalnikov v glasbeni analizi, kakršna je bila značilna za petdeseta leta 20 . stoletja.
Keywords: computer-assisted music analysis, information theory, development of early computers

\section{SUMMARY}

This article is the first of a series that focuses on the history of computer-assisted music analysis. This first article discusses the philosophical basis of computer-assisted music analysis, i.e. the application of information theory to aesthetics, as well as representative applications of statistical and information-theoretical measurements to music analysis and other computational approaches to music analysis that did not include the use of electronic computers. In most cases, those approaches were direct models for computerassisted applications. Finally, this article provides a short historical account of the development of early computers and summarizes the earliest computerapplications to music analysis, carried out during the 1950s. 
"I should like to suggest that computer analysis will become one of the most important directions in musicology for the next generation. One hears frequently the comment that computers will make musicology mechanistic. Bear in mind, however, that the computer does what it is told: even its most sophisticated procedures depend on the imagination of the researcher for instructions; and the final results always require further interpretation. In these two functions - instruction and interpretation - the researcher controls the fundamental musicality of the investigation. If the results are mechanistic, he cannot blame the computer." (Jan LaRue 1970, 197.)

\section{Introduction}

This article shall be the beginning of a series of articles on the history of computer-assisted music analysis. Computer-assisted music analysis, which emerged about 50 years ago, provicles analytical tools that help solve problems, some of which may be unsolvalble without the assistance of the computer. Unfortunately, most research in the area of computer-assisted music analysis has been carried out, again and again, without any explicit review of preceding attempts and accomplishments. Even the most recent research bears traces of two fundamental flaws that have plagued most research carried out to date: there is no classification of analytical methods within a comprehensive historical framework, and there is no critical evaluation of those methods.

A series of articles will attempt to solve the main problem related to these flaws: to provide a historical account and framework of methods of computer-asisted music analysis. The source materials for the historical account consist of nearly 2,000 published and unpublished writings, including dissertations and internal research papers from many countries, that were collected and analyzed over many years.

The first part of this article focuses on the philosophical basis of computer-assisted music analysis, i.e. the application of information theory to aesthetics. The second part describes representative applications of statistical and information-theoretical measurements to music analysis and other computational approaches to music analysis which did not include the use of electronic computers ${ }^{1}$. In most cases, those approaches were direct models for computerassisted applications, and an understanding of the development of computer-assisted analysis is not possible without the knowledge of these early approaches that used no computer. The third part of this article provides a short historical account of the development of early computers and summarizes the earliest computer-applications to music analysis, carried out during the 1950 s.

\section{The Philosophical Foundation: Information Theory and Aesthetics}

Richard Pinkerton wrote alrealy in 1956: "Information Theory may well prove generally useful for studying the creative process of the human mincl. I don't think we have to worry that such analysis will make our art more stilted and mechanical. Rather, as we begin to understand more about the property of creativeness, our enjoyment of the arts should increase a thousandfolkl." (Richard C. Pinkerton 1956, 86) The results predicted by Richard C. Pinkerton have hardly been realized. But especially with regard to certain developments in the area of

I Joseph Schillinger (1948) provided detailed descriptions of mathematical relationships in music, but he wals not primarily trying to provide a methodology for music analysis or for composition. For that reason, Schillinger's work will not be discussed here. 
Artificial Intelligence during the 1990 s, research has produced results that came much closer to Pinkerton's vision of the usefulness of information theory for studying creative processes.

Pinkerton was one of the first to explore the application of information theory to music, specifically to music analysis. The philosophical rationale, however, was ultimately provided by several people: George D. Birkhoff (1931, 1950), Abraham Moles (1956a, 1956b, 1958, 1962, 1966), and by Max Bense (1954, 1966, 1969) and his disciples Helmar Frank (1964, 1968), Rul Guntzenhäuser (1962), Siegfried Maser (1971), and Frieder Nake (1974). Using information theory, all of those people sought either to explain some aspects of aesthetic reflection and artistic cognition, or both, or to analyze or synthesize 'artistic artifacts'.

Information theory itself was based on a model, partly mathematical and partly physical, relating to the transmission and reception of messages ('information'). In this context, information was related to the potential variety of messages in contexts and the probabilities of messages. For instance, if a melodic phrase in a piece of music occurs for the first time, it is an unexpected event, i.e. it has a probability of zero; hence, it has a high degree of originality and it "modifies the behavior of the receptor" (Moles 1967, 22). If a melodic phrase occurs many times, its probability increases, and the originality, the degree of 'information,' decreases. In 1949, Claude E. Shannon defined a measure of information, called 'entropy,' as a logarithmic function of the statistical probabilities of different messages. (See Shannon and Weaver 1949, $49 \mathrm{ff}$.) Thus, information was considered measurable to the extent that it could determine how predictability and unpredictability relate to the variety of a system.

Taking a different tact, Bense's aesthetics had its origin in the theory of signs. His attempts to create a mathematical notion of aesthetics, a quantitative, descriptive notion he called 'information aesthetics' ['Informationsästhetik'], came out of his interest in cybernetics, and was based on the analytical procedures described by the US-mathematician and physicist George David Birkhoff. In the 1920s, Birkhoff had tried to develop a formula for dealing with aesthetics, defining aesthetic measure $(\mathrm{M})$ as a quotient of the order $(\mathrm{O})$ of an 'aesthetic object' and its complexity (C): $\mathrm{M}=\mathrm{O} / \mathrm{C}$. (See Birkhoff 1950, 288-306, and 320-333.)

Moles, on the other hand, in his 'aesthetic perception theory', based his theory on the evaluation of experimental data and statements, an evaluation in which the relation of innovation and redundancy was very important. (See Moles 1958.) Moles distinguished between semantic information and aesthetic information, a distinction based on the insight that Shannon's information theory was hardly applicable to the analysis of art works in terms of their artistic value ('aesthetic information'), but instead was related to what he called the 'inner structure' of these art works ('semantic information'). ${ }^{2}$

Responding to the aesthetic theories of Bense and Moles, Helmar Frank proposed an 'exact information theory' (Frank 1964, 1968). He combined automata theory, system theory, and sign theory, with information theory and theories drawn from experimental psychology. To define his 'subject model' mathematically, using theories of automata (i.e., the subject is viewed as the addressee of the message, which is the work of art), he needed such categories as 'surprise value' ['Überraschungswert'] and 'conspicuousness value' ['Auffälligkeitswert']. Frank's integration of empirical research and experimental psychology in his theory is even more important than his theory per se. In this sense, his theory can be seen as an early case of cognitive research like that done in the 1980 s and 1990 s.

A follower of Bense, Siegfried Maser (1971), proposed the creation of a numerical aesthetics' ['Numerische Ästhetik'], derived from Baumgarten's definition of aesthetics as the

2 An overview of "Aesthetics of Music and Information-Theory," mainly balsed on Moles' theory, was also given by Jan L. Broeckx (1979, 105-125). 
science of the critical assessment of beauty. Maser interpreted Baumgarten's model of aesthetics as an objective, scientific aesthetics, based on three sciences: the 'science of the real' ['Realwissenschaft'], the 'science of the formal' ['Formalwissenschaft'], and the 'science of the intellect' ['Geisteswissenschaft']. He proposed distinctions between 'macro aesthetics'. ['Makroästhetik'] and 'micro aesthetics' ['Mikroästhetik'] in the process of formulating a 'complete aesthetic analysis'5 ['vollständige ästhetische Analyse'] (Maser 1971, 91). Maser's method of an 'aesthetics by measurement' ['Maßästhetik'] is based on the precise quantitative description of objects, which he sees as the 'rational basis' for an 'aesthetics of value' ['Wertästhetik']. He thinks that the more rigorously the rational basis for the formulation of values is defined, the more convincing will be the speculations and conceptions derived from this basis. ${ }^{6}$

All of the attempts mentioned above, which tried to describe aesthetic artifacts with mathematical methods, specifically with methods derived from information theory, were relatively unsuccessful in formulating meaningful philosophical generalizations about works of art. The failure to distinguish different levels of aesthetic information contained in art works was one of the main reasons for the lack of success (see, for instance, Kasem-Bek 1978). Although the mathematical description of complex aesthetic processes and attempts to calculate aesthetic values produced few significant results, the application of information theory to the analysis of structural norms of art works, specifically of motives and phrases, clid produce some significant results. ${ }^{7}$ Since repetition of musical structures is responsible for creating musical form, the analysis of musical structures based on the measurement of redundancy was fruitful, particularly when it was embedded in observations of musical form. ${ }^{8}$

\section{On Predecessors and 'Relatives' of Computer-Assisted Music Analysis}

Otto Ortmann was an important pioneer of statistical analysis of music. His article from 1937, still virtually unnoticed, involved an analysis - certainly conducted without an electronic calculator-that was restricted to interval frequencies of song melodies by Robert Schumann (48 songs), Johannes Brahms (38 songs), and Richard Strauss (40 songs). No distinction was made between ascending and descending intervals; intervals of equal distance but different nomenclature (e.g. augmented second and minor third) were grouped together. Ortmann calculated the interval distributions of each song and an interval average for all the songs by each composer, the percentage of songs by each composer in which every specific interval was present, and the range of positions which every interval holds-with regard to its frequencyin most of the songs. No matter what the specific results ${ }^{9}$ may be worth, and no matter how

4The formula for calculating the 'Macro Aesthetics' is: Macro Aesthetic Measure $\left(M_{A E}\right)=$ Order $/$ Complexity.

4 The formula for calculating the 'Micro Aesthetics' is: Micro Aesthetic Measure $\left(M_{a x}{ }^{2}=\right.$ Entropy / Redundancy.

5 The formula for calculating the 'Complete Aesthetic Measure' is: Macro Aesthetic Measure $(\mathrm{AE})=\left[\left(\mathrm{M}_{\mathrm{AE}}+\mathrm{M}_{\mathrm{ac}}\right) / 2\right]$ birk.

6 "Je priziser alber diese rationale Basis formuliert wird, desto überzeugender wirken die darauf begründeten Spekulationen und Wertkonzeptionen." (Maser 1971, 125).

7 Regarding aesthetic perception, Coons and Kraehenbuehl $(1958,128)$ call this the level of concept formation. It goes beyond the level of simple perception. In the same article, they also suggest defining information as a quotient of 'nonconfirming tests of predictions' and 'predictions tested' (ibid., 139). See also Krathenbuehl and Coons 1959.

8 This notion was already supported in the theoretical articles (i.e. with no practical analyses of music) by Leonard B. Meyer (1957), Joel $\mathrm{E}$. Cohen (1962), Fritz Winckel (1964), and later by Alfred Huber (1974) and others.

- Some parts of each distribution, based on songs by different composers, were similar to each other. Others were different, and thus interpreted as "characterizing" for the composer's style. For Schumann, the predominance of unisons, the relative absence of wide intervals and of chromatic inflection, and the consistency with which the frequency order unison - major second - minor second is found (in $65 \%$ of the songs) was characteristic (Ortmann 1937, 7). Characteristics of Bralum's songs were the relative alssence of unisons, the preference for thirds (especially minor thirds), the frequency order major second - minor second - unison (in $45 \%$ of the melodies), and-"not very pronounced" - the preference for chromatic inflection (ibid., 6 ff.). Finally, characteristics in Strauss' melodies based on interval frequency (except a slightly predominant use of sixths) were not found (or, in other words: a uniformity is typical); in different ways, the distributions were similar to the songs by both of the other composers, Schumann and Brahms (ibid., 8 f.). This certainly shows the limitations of this approach, which Ortmann himself was aware of. - In general, Ortmann concluded a "chronological tendency towards an increase in pitchmotion" (ibid., 9). 
the question of what validity these results hold generally for songs written by these composers, Ortmann must be given credit for initiating a new form of analysis and for being self-critical enough to point out the disadvantages of disregarding other musical (and non-musical) parameters.

In 1949, Bertrand Bronson described a procedure for using an electro-mechanical calculator-not a 'computer'-to carry out a comparative study of British-American folk-tunes. He used punched cards for encoding general information (publication, collector, singer, etc.), regional information, and musical characteristics, such as range, mode, time signature, number of phrases, phrasal scheme, final tone, initial interval between the upbeat and the first strong accent, etc. Then, the sorting machine was able to automatically pick out cards with desired characteristics. Thereby, certain musical characteristics could be matched with certain geographical origins, etc. Results of this theoretical procedure were published ten years later (Bronson 1959).

A similar, but much more sophisticated, system called cantometrics was developed by Alan Lomax. It is a system for rating song performances by qualitative judgements. ${ }^{10}$ Rhythmic, melodic, instrumental, tempi, and other performance characteristics, as well as text characteristics, were initially encoded with a 37 digit rating scale, i.e. the number of slots on an IBM punch card. The system became, later, the model for further computer-assisted studies (as, for instance, described in Grauer 1965).

Even though Pinkerton (1956, 84) claimed that Allen 1. McHose (1950) was one of the first to use "modern techniques" for analyzing music, McHose did not mention any use of computers in his analyses. However, his statistical analyses of the chord structure of Bach chorales are of importance for later computer applications in harmonic analysis. In his study from 1950, McHose calculated the frequency of chord types, harmonic functions, inversions, etc., as well as the frequency of non-harmonic tones. He also compared root movements and types of chords in works by Johann Sebastian Bach, Georg Friedrich Händel, and Carl Heinrich Graun. But while computer technique, at the time, was not advanced enough to handle McHose's calculations, this kind of study became the direct predecessor of a type of computerassisted harmonic analysis which evolved in the 1960 s.

H. Quastler reported in $1956^{11}$ that Fred and Carolyn Attneave had analyzed cowboy songs and obtained the transition probabilities for every note preceding a particular note. Based on the analytical results, they tried to synthesize "a few dozen" new songs in the same style, but only two of them were "perfectly convincing" (ibid., 169).

Until the mid-1950s, only simple statistical calculations were applied to music analysis, but Linton C. Freeman and Alan P. Merriam in 1956 used a more complex statistical method for the differentiation of two bodies of music: the discriminant function. The discriminant function uses multiple measurements to discriminate between two groups of music. In this case, the two groups of music were songs of Trinidad Rada and of Brazilian Ketu. Three characteristics were examined: the mean values of frequencies of (1) major seconds and (2) minor thirds in proportion to the lengths of the song, as well as (3) the total interval use. While each separate characteristic showed insufficient discrimination of the two groups of songs, ${ }^{12}$ the use of the

\footnotetext{
1" Lomax' system is based on the hypothesis that "music somehow expresses emotion; therefore, when a distinctive and consistent musical style lives in a culture or runs through several cultures, one can posit the existence of a distinctive set of emotional needs or drives that are somehow satisfied or evoked by this music," (Lomax 1962, 425) See also Lomax 1976. However, Lomax's theory is not undisputed; see, for instance, Kongas-Maranda 1970, Henry 1976, Kolat:a 1978, Berrett 1979, Locke 1981, and Oehrle 1992.

11 Quastler's report is part of the discussion, following the article of Fucks 1955, pp. 168-169. For F. and C. Attneave themselves, the results were probably not satisfactory enough for publication.

12 The mean differences for major seconds and minor thirds were each significant beyond the one percent level of confidence, but not in the total interval use. However, the overlaps between the two groups of songs in each separate characteristic were too large.
} 
discriminant function reduced the probability of misclassifying a single song. However, only 3 measures each of interval use from a very small sample of only 20 songs diminished the statistical value of the results. Nevertheless, using a complex statistical method was innovative in that it provicled a method useful for a more sophisticated, computer-assisted analysis of music that took place in the following decade.

In 1956, Richard C. Pinkerton published a study on "Information Theory and Melody." In this article, he discussed entropy analysis (i.e., the analysis of the statistical degree on 'information' in music) and redundancy analysis ${ }^{13}$ and how each related to the analysis of 39 nursery songs. Even though all calculations were done manually, his approach was already designed to make use of computer assistance (see Pinkerton 1956, 86). Based on the analytical results of pitch and rhythm probabilities, Pinkerton designed a network of tone relations which enabled him to define a compositional procedure to create similar tunes. (However, his 'composed' melodies were "highly monotonous" [ibid., 84].) Pinkerton's network and transition patterns could be seen as early implementations that relate to concepts that have emerged recently in neural network research: "Thinking of our network scheme, it is fun to speculate that a composer's individual style may reflect networks of nerve pathways in his brain." (Ibid., 86.)

Joseph E. Youngblood's applications of information theory to music analysis (Youngblood 1958, 1960) were probably the most extensive studies of all those that could be called the direct 'predecessors' of computer-assisted music analysis. His ambitious calculations showed the need for computer-assistance. Youngblood's attempts to identify and define musical styles was based on the assumption that musical style can be characterized by a stochastic process, specifically a process that can be characterized using a "Markov chain"14 (Youngblood 1960, 14-15). Youngblood selected song melodies by Franz Schubert, Robert Schumann, and Felix Mendelssohn, and calculated frequencies and probabilities of each scale clegree, tone entropies and redundancies, as well as first-order-transition-probabilities for each melody. Some of the results showed, for example, that Mendelssohn used chromatic tones less frequently than Schubert or Schumann, and that Mendelssohn's music was more redundant. Youngblood also compared those results to analyses of samples of Gregorian Chant. Almost all of Youngblood's results did not show statistical differences clearly enough. Due to the number of songs sampled and clue to the false assumption that redundancies of melodies alone could characterize a musical style, Youngblood's results were not very significant. ${ }^{15}$

The analyses of musical rhythm by John G. Brawley (1959) were intended to provide a means to characterize style. Assuming music to be a discrete system of communication and assuming that music is an ergodic stochastic process that has the structure of a stationary Markov chain, Brawley calculated entropy and redundancy of selected pieces from different time periods. However, Brawley stated himself-with regard to an analysis of a Bach

13 Pinkerton calculated specifically entropy and redundancy of single tones as well as transition probabilitit:t, Entropy is a fon of measurement found in the conceptual methodology of information theory and is not related to semantics, but to syntax. lt is an index of the degree of 'information' found by analyzing single elements (e.g., pitches or tone durations) or groups of elements taken as a unit. In the latter case, the entropy is of 'higher order'. The entropy is specifically the negative sum of all logarithms of the probability of each event multiplied by the probability of each event. (Shannon 1949 , pp. 49 foll.) The average entropy of a melocly, for instance, is the negative sum of all logarithms of the probability of each note multiplied by the probability of each note. In casc of calculating the entropy of the second order, the specific succession of two notes are seen as one element. Redundancy is a measurement, taken from information theory, that gives information about the partial (or complete) repetition of 'message content', i.e. clements. For instance, if there is an increasing number of a certain pitch or a certain melodic phrise, the entropy of this pitch or melodic phrase decreases and the redundancy increases. Transition Frequency is the frequency with which certain elenents (e.g., pitches) occur in some places, when it is known that certain others occur in previous places. Transition Probability is the probalility of an element (e.g., a note or a group of notes) which follows another specific element (note or group of notes).

14 A Markov Chain is a model for a sequence of events in which the probability of a given event (or grouping of events, i.e. event of 'higher orders') is dependent only on the preceding event (or event of 'higher orders'). For instance, the probability of a sequence of five pitches, i.e. a group of pitches of order five, would be dependent only on the preceding group of five pitches.

15 In comparison with Youngblood. Joel E. Cohen $(1962,152)$ applied the same analytical methods to the analysis of two Rock and Roll songs. However, the critique given here for Younglblood's research is especially true for Cohen's. 
invention-"that this analysis employing information theory is not very valuable. At best, it may tell us a little about this particular invention, but hardly more than we could arrive at by a less exhaustive and less painstaking analysis." The number of samples used was too small to warrant drawing general conclusions. However, Brawley's conceptual approach became the basis for more successful rhythm research that followed years later.

Just as philosophical generalizations derived from information theory were applied in a highly limited way (see 1.), mathematical (statistical) approaches were applied to the analysis of simple 'aesthetic objects' in a similar limited manner:

Wilhelm Fucks' "mathematical analyses of the formal structure of music"16 became an important precedent for the development of computer applications (although Fucks" calculations were still made without the computer) ${ }^{17}$, as well as for the elaboration of the application of information theory to aesthetics (see, e.g., Bense 1969). Fucks' music-analytical attempts were connected with his attempts to analyze language (e.g., Fucks 1956, 1964). His analyses of musical compositions were usually linited to the analysis of pitch and tone duration in selected voices. Even though his list of publications is long, most of Fucks' writings are based on the same, or similar, data. Fucks usually calculated probabilities, transition probabilities, averages, standard deviations ${ }^{18}$, kurtosis $^{19}$ and skewness ${ }^{20}$ of distribution curves, as well as entropies. In Fucks' analysis from 1958, for instance, his musical materials were limited to the first violin parts of some concertos, symphonies and symphonic poems, and to the soprano parts of some masses (Fucks 1958, 9 f.). While results of his earlier research showed a correlation between composer, time of composition, and frequencies of pitch and tone duration, later pulblications, especially Fucks' analyses of 1963, demonstrated that standard cleviation and entropy of pitches (independent of each other) increases monotonously with the time of composition. Transition matrixes of pitches and transition matrixes of intervals provided information on the probabilities of pitches and intervals following each other. Based on the transition matrixes, Fucks calculated correlation ellipses ${ }^{21}$. Finally, W. Fucks and J. Lauter (1965) calculated auto-correlations of pitches and intervals.

At the time, Fucks' methodological approach was already quite complex in its mathematical form, especially with regard to the comparison of different frequency distributions (pitches, tone durations, intervals, and tone pairs) and its comparison to stochastically-generated music. As such, Fuck's approach revealed the significant potential of mathematical analysis of style. However, Fucks' conclusions were very restricted to specific selections of compositions, and his generalizations of epoch characteristics were far-fetched. An important factor for the restricted analytical outcome was the missing distinction between genre characteristics and personal style in music.

Fucks' methods and analytical results were harshly criticized and shown to be erroneous by Günther Wagner (1976). Wagner noticed "that relative interval-frequencies of consecutive tones cannot be seriously considered either for the question of authenticity or for the proof of a

16. See, for instince, fucks 1957, 1958, 1962, 1963, 1964 and 1968, as well as fucks and latuter 1965.

1- Even though kejaren Hiller $(1964,10)$ mentioned that Fucks used already a computer for his study in 1958, there is no indication for the usc of computers in any of Fucks' writings themselves.

is Variance and standard deviation give information about the distribution of the elements (e.g. pitches, tone durations, or intervals) around the mean, i.e. the average distance of all elements from the mean. The variance is calculated by permanently subtracting the mean from each element, squaring all results, adding them together and dividing them by the total number of all etements minus one. The standird deviation is the square roo of the variance; it refers to the average distance of elements (e.g., pitches) from their mean value.

1" Kurtosis refers to the flatnes or peakedness of a (distrilution) curve, relative to the size of the standard deviation.

I" Skewness refers on a (distribution) curve, which is asymmetrical.

2 Correlation gives information on the relationship berween two (or more) characteristics, e.g. if two characteristics such as pitch and tone duration are dependent on one another linearly or not. 
historical development" (ibid., 67)22. He pointed out "that the standard deviation in compositions of the same genre and the same composer might vary as much as between compositions of different genres by composers, which belong to different epochs" (ibid.) ${ }^{23}$. And finally, he showed "that the relative pitch distribution is completely ruled out as a method for answering questions about authenticity or chronology" (ibid., 69).2-1

A more reliable music theoretical foundation was provided by Walter Reckziegel (1967a, 1967b, 1967c), a disciple of Fucks, in an extension of Fucks' notion of 'exact scientific' ['exaktwissenschaftlichen'] methods. In his analyses, Reckziegel included the calculation of metrical units and of musical intensity. For this purpose, Reckziegel defined formulas for calculating the entropy of the metrical unit and the 'total entropy', which is the product of the entropy value $(\mathrm{H})$ of $u$ different pitches and $v$ different tone durations $[\mathrm{H}(\mathrm{u}, \mathrm{v})]$ and of the different pitches $\mathrm{u}: \mathrm{u} \cdot \mathrm{H}(\mathrm{u}, \mathrm{v}) .{ }^{25}$ Furthermore, he calculated the 'Bewegtheit' [kind of motion] out of the impulse frequency per metrical unit, 'intensity' and 'density' (arithmetic mean of metrical units). Sound structures and 'complexities' were analyzed (deliberately) without considering harmonic progressions. Reckziegel's attempts show the desire to formulate methods that can deal with a musical complexity greater than that attempted by Fucks' analyses. However, Reckziegel's analyses were still limited with regard to the number and kind of mathematical calculations.

About ten years later, Christian Kaden (1978) discovered an interesting connection between statistical (not computer-assisted) and traditional music analysis, including psychological and sociological aspects. Analyzing the second movement (Allegretto scherzando) of Beethoven's symphony No. 8 op. 93, Kaden tried to verify his intuitive analytical judgment by statistically calculating dependencies of elementary structures (Gestalt units), mathematically describable as tone probabilities of higher orders. ${ }^{26}$ Kaden's approach was very successful, and his methodology could have been easily adopted for computer-assisted analyses.

Generally, researchers interested in non-computer-assisted approaches to music analysis drawing on mathematics, statistics, and information theory developed an important repertoire of analytical methods that could easily be formalized in computer programs. From today's point of view, most of these approaches have to be evaluated very critically, but without them computer-assisted music analysis could not have emerged.

\section{Computers and Computer-Assisted Music Analysis During the 1950s}

Even in the beginning of the 'computer age' of music analysis, communication between scholars was very slow. At one of the first early conferences on computer applications in music (1965), Edmund Bowles phrased this problem as follows: "There exists no clearinghouse, no center of information, no means of intercommunication between scholars in the humanities using the tools of clata processing. Currently existing journals and learned societies are reluctant to assume this additional burden, especially outside their own discipline. We need more scholarly convocations such as this one. We need to avoid needless duplication of effort." (Bowles 1970, 38.) Since then, some journals have come into being, and more and

\footnotetext{
22 ". . . daß relative Intervallhäiufigkeiten konsekutiver Töne wecler für Echtheitsfragen noch für den Naclıweis einer historischen Entwicklung ernsthaft in Frage kommen können."

23 ". . . daß die Sigmawerte [Standardabweichung, N.S.I in Werken ein und derselben Gattung des gleichen Komponisten ähnlich schwanken können, wie zwischen Werken unterschiedlicher Gattungen von Komponisten, die unterschiedlichen lipochen angehören."

24 “. . daß die relative Tonhöhenverteilung als Mittel zur Lösung von Fragen der Echtheit oder Chronologie gïinzlich ausscheidet."

25 The exact formulas can be found in Reckziegel 1967a, 16-17.

2t The basis for this approach, the structural segmentation of music, was already descrilued and explatined in deatil by Kaden in 1976 .
} 
more conferences on the topic have been organized. However, after looking at the publications in the area of computer-assisted music analysis, it seems that not much has changed since the 'beginning': scholars know little about the history of their area, previous successes and failures are hardly known. Thus, mistakes are duplicated, and prejudices florish. Ultimately, a detailed history of computer-assisted music analysis is needed. The following paragraphs will give a brief overview of the developments of early computer technology through the 1950s. Finally, the earliest project on computer-assisted music analysis, the only one completed during the 1950 s, is summarized.

The first fully electronic computer was the "ENIAC" (Electronic Numerical Integrator and Calculator), developed by John Presper Eckert and John Mouchly in 1946. Although it made calculations about one hundred times faster than calculations by a mechanical differential analyzer, it took a long time to re-program, i.e. re-wiring, the machine. Other problems were too little storage (only twenty numbers!) and too many tubes. However, after the famous mathematician John von Neumann became a consultant to the ENIAC project in 1944, deficiencies were resolved and a new design was developed. It was one of the most crucial designs for further computer developments: The idea of the "stored-program computer" was born, outlined in a plan for the post-ENIAC "EDVAC" (Electronic Discrete Variable Automatic Computer). Virtually all computers up to the present have been based on the John-vonNeumann-principle of "stored programs" — using the same memory for numbers as well as for instructions - enabling a rapid change from one program to another. After von Neumann's design, computers have had five functional divisions: input, memory unit, control unit, arithmetic unit, and output. Other new features were the use of binary numbers (ENIAC still used decimal numbers), and the serial execution of instructions.

While EDVAC was never actually realized, in 1949 Maurice V. Wilkes' "EDSAC" (Electronic Delay Storage Automatic Calculator) became the first full-scale universal digital computer with saved programs based on John von Neumann's principles. Because of its saved programs, software design came into being with EDSAC. Eventually, programs were developed which translated other programs into machine code and could, thus, be understood by the hardware. In the second half of the 1940s, IBM became the leading company in the computer industry. The "Card Programmed Calculator" became - in the late 1940s and early 1950 s - the most often sold calculating tool. However, by the end of the 1940s, IBM had developed several fullscale computers. IBM also developed the magnetic drum for the main memory (instead of mercury delay lines or electrostatic storage tubes). Having established their own computer business, J. P. Eckert and J. Mouchly developed similar devices. After being taken over by Remington Rand, Eckert and Mouchly completed the development of their UNIVAC (UNIVersal Automatic Computer; 1951). It was the world's first commercially available fully electronic computer, and it became a market leader for its type. The UNIVAC was eventually the first computer the broader public had been introduced to during election night 1952, when it accurately predicted Eisenhower's win over Stevenson. After that, 'UNIVAC' became a generic name for computers.

The prediction of the election outcome also showed the great potential for computers in data processing for many business areas. Thus, in the early 1950s, there was a change of the main use of computers: a change from mathematical calculations to data processing. Dozens of computer businesses - mainly in the United States - emerged. Most of them were eventually acquired by bigger office-machine firms. IBM developed several computer models during the 1950s and became the market leader. The low-cost Magnetic Drum Computer (IBM 650; 1953), for instance, was acquired by many institutions of higher learning. Other institutions of higher learning started to develop their own computers. 
The first extensive, systematic use of an electronic computer for music-analytical purposes was described by the mathematician Frederick P. Brooks et al. in 1957. Brooks conducted an analysis-synthesis-project at the Computation Laboratory at Harvard University ${ }^{27}$. For this project, high-order probabilities of 37 hymn tunes were calculated. Those probabilities were then used for the synthesis of new melodies, using Markov chains of orders one through eight. Even though this experiment was limited to (melodic) samples that were not structurally complex, this procedure "permitted the production of a significant number of acceptable tunes within a reasonable time." (Ibid., 180) ${ }^{28}$

While Brooks' experiment is rarely mentioned in the literature, the work of Lejaren A. Hiller and Leonard Isaacson has been extensively noted, specifically their work on the Illiac Suite (String Quartet No. 4) is mentioned in almost every textbook on electronic music. ${ }^{29}$ The Illiac Suite was composed with the ILLIAC computer in 1956 at the University of Illinois. Even though the computer was, in this composition project, not used for analysis but for the generation and selection of random values in a type of stochastic modeling (known as the "Monte Carlo Method") ${ }^{30}$, Hiller's and Isaacson's importance for computer applications in music goes beyond composition. In their book (Hiller and Isaacson 1959), they suggest several computer applications to music analysis:

- statistical and information theoretical applications,

- analysis of musical similarity,

- pattern search,

- analysis of sounds and their physical constitution,

- optical music recognition,

and based on analytical results:

- realization of continuo and figured bass and to complete part writing,

- missing parts could be reproduced based on statistical style analysis,

- systematic generation of musical materials for teaching purposes.

(See ibid., 165-170.) Most or all of these suggestions were launched during the late 1950 s and and early 1960. Their results have been described, for example, in Hiller 1962 and 1964.

\section{Concluding Remarks}

With the applications described above, the history of computer-assisted music analysis goes far back to applications of information theory to aesthetics, which provided the philosophical basis of statistical and mathematical music analysis, as well as to (practical) mathematical approaches to music analysis that were not completed with a computer. The approaches that did not use computers continue to this day. The first real computer-application was completed between 1955 and 1957 by a team around the mathematician Frederick P. Brooks. While Hiller and Isaacson used pre-determined "rules" for their Illiac-Suite from 1956, Brooks et al. derived the compositional rules automatically. As such, the project by Brooks et al. was the only completed project of

27 Younghlood 1960 also mentioned an unpulblished term puper from 1955 by $\mathrm{F}$. P. Brooks, which lets assume that Brook's project was aiready realized in 1955. The computer used was the Harvard MARK IV. See Youngblood 1960, 23, footnote 42. In addition, see Neumann and Schappert 1959.

2s For sample melodies see ibid. Neumann and Schappen 1959, which contains the description of the project in German, also reprinted some of the melodies.

3) Brooks' paper was not widely available, whereas Hiller's and Isaacson's book (1959) became available in almost every library.

so The Monte Carlo Method is a method of obtaining an approximate solution to a numerical problem by the use of random numbers. In music, this method was first applied to composition by Hiller and Isaacson (1959). Here, rindom sequences of integers were equated to notes, durations, dynamic values and playing techniques. These random integers were then screened by applying various rules and rejected or accepted, ckepending on the rules. 
computer-assisted music analysis of the 1950s, and it was part of an analysis-synthesisapproach, i.e. the main purpose of analytical calculations was to compose. One need to keep in mind that computers were, at the time, rarely available for music research. However, the many statistical analysis projects that did not use computers as well as Hiller's and Isaacson's vision of future research on computer-assisted music analysis gave directions for more sophisticated computer-assisted music analysis of the 1960 s.

\section{Bibliography}

Bense, Max. 1954. Aesthetica. Stuttgart: Deutsche Verlags-Anstalt.

Bense, Max. 1966. "Ästhetik und Programmierung." IBM-Nacbrichten 16 (1966): 294-296.

Bense, Max. 1969. Einfïbrung in die informationstbeoretische Ästbetik. Reinbek bei Hamburg: Rowohlt. Berrett, Joshua. 1979. "Alan Lomax: Some Reconsiderations," Joumal of Jazz Situdies VI/1 (1979): 54-63.

Birkhoff, George David. 1931. "A Mathematical Approach to Aesthetics." Scientia, September 1931: 133-146.

Birkhoff, George David. 1950. Collected Mathematical Papers, vol. 3. New York: American Mathematical Society.

Bowles, Edmund. 1970. "Discussion," Musicology and the Computer: Three Symposia, ed. by Barry \$. Brook. New York: The City University of New York Press. 37-38.

Brawley, John Gray. 1959. An Application of Information Theory to Musical Rhythm. M.M. thesis. Indiana University.

Broeckx, Jan L. 1979. Contemporary Vieus on Musical Style and Aesthetics. Antwerp: Metropolis.

Bronson, Bertrand H. 1959. "Toward the Comparative Analysis of British-American Folk Tunes." Joumal of American Folklore LXXII (1959): 165-191.

Bronson, Bertrand H. 1949. "Mechanical Help in the Study of Folk Song." Joumal of American Folklore LII (1949): 81-86.

Brooks, Frederick P., A. L. Hopkins, P. G. Neumann, and W. V. Wright. 1957. "An Experiment in Musical Composition." IRE Transactions on Electronic Compulers VI (1957): 175-182. (An errata see in vol. 7 (1958): 60.) Reprinted in Macbine Models of Music, ed. by Stephen M. Schwanatuer and David A. Levitt. Cambridge, MA: The MIT Press, 1993. 23-40.

Cohen, Joel E. 1962. "Information Theory and Music," Behavioral Science VII/2 (April 1962): 137-163.

Cohen, Joel E. 1964. "Teorie informaci a hudba," Nové Cesty Hudby (1964): 180-215.

Coons, Edgar, and David Kraehenbuehl. 1958. "Information as a Measure of Structure in Music," Joumal of Music Theory II (1958): 127-161.

Freeman, Linton C., and Alan P. Merriam. 1956. "Statistical Classification in Anthropology: An Application to Ethnomusicology," American Antbropologist 58 (1956): 464-472.

Frank, Helmar. 1964. Kybenetische Analysen subjektiver Sacbverhalte. Quickborn bei Hamburg: Schnelle.

Frank, Helmar. 1968. Informationsësthetik. Grundlagenprobleme und erste Anuendungen auf die mime pure, $3^{\text {rd }}$ ed. Quickborn bei Hamburg: Schnelle.

Frank, Helmar. 1997. Ästhetische Information : eine Einfübnung in die kybemetische Ästhetbik. Berlin: Institut für Kybernetik.

Fucks, Wilhelm. 1955. Mathematiscbe Analyse von Spracbelemente, Sprachstil und Spracbe. Köln: Westdeutscher Verlag.

Fucks, Wilhelm. 1956. "Mathematical Theory of Word Formation." Information Theory, ed. by Colin Cherry. London: Butterworths Scientific Publications, 154-170.

Fucks, Wilhelm. 1957. "Gibt es mathematische Gesetze in Sprache und Musik?" Umschan in Wissenschaft und Technik 1957, no. 2: 33-37.

Fucks, Wilhelm. 1958. Mathematische Analyse der Formalstruktur von Musik. Köln: Westdeutscher Verlag.

Fucks, Wilhelm. 1962. "Mathematische Musikanalyse und Randomfolgen. Zufall und Musik." Gravesaner Blätter vol. VI (1962): 132-145.

Fucks, Wilhelm. 1963. Matbematische Analyse von Formatstmkturen von Werken der Musik. Köln: Westdeutscher Verlag.

Fucks, Wilhelm. 1964. "Gilt es mathematische Gesetze in Sprache und Musik?" Kybernetik, ed. by Helmar Frank, $4^{\text {th }}$ ed. Frankfurt am Main: Umschau Verlag, 175-187.

Fucks, Wilhelm. 1968. Nach allen regehn der Kunst. Diagnosen über Literatur, Musik, bildende Kunst - die Werke, ibre Autoren und Schöpfer: Stuttgart 
Fucks, Wilhelm, and Josef Lauter. 1965. Exaktwissenschaflicbe Musikanalyse. Köln: Westdeutscher Verlag. Goldman, Stanford. 1953. Information Theory: New York: Dover.

Grauer, Viktor A . 1965. "Some Song-Style Clusters-A Preliminary Study." Ethnomusicology IX (1965): 265271.

Guntzenhäuser, Rul. 1962. Ästbetisches Maßs und ästhetische Information. Einfiubrung in die Theorie G. D. Birkboffs und die Redundanztheorie ästhetischer Prozesse. Quickborn bei Hamburg: Schnelle.

Henry, Edward O. 1976. "The Variety of Music in a North Inclian Village: Reassessing Cantometrics," Elhnomusicology XX/1 (1976): 49-66.

Hiller, Lejaren A., Jr. 1962. Information Theory and Musical Analysis. Mimeographed. Urbana: University of Illinois, Experimental Music Studio. Technical Report No. 5, July 1962. 40 p. (University of Cincinnati Library, MUS ML 3817 .I4 no. 5).

Hiller, Lejaren A., 1964. Informationstbeorie und Computermusik. Darmstädter Beiträge zur Neuen Musik 8. Mainz: B. Schott's Söhne.

Hiller, Lejaren A., and Leonard M. Isaacson. 1959. Experimental Music. Composition witb an electronic computer. New York: McGraw-Hill.

Huber, Alfred. 1974. "Informationstheoric und Musikanalyse," Melos XLI/4 (July-August 1974): 207-210.

Kaden, Christian. 1976. "Strukturelle Segmentierung von Musik - Probleme, Schwierigkeiten, Möglichkeiten," Beiträge zur Musikuissenschaft 18 (1976): 149-162 and 293-334.

Kaden, Christian. 1978. "Ludwig van Beethoven, Sinfonic Nr. 8, zweiter Satz, Allegretto scherzando. Ansätze zu einer statistischen Strukturanalyse." Bericht aber den Intemationalen Beetboven Kongreß3 20. bis 23. März 1977 in Berlin, ed. by H. Goldschmictt, K.-H. Köhler, and K. Niemann. Leipzig: Deutscher Verlag für Musik, 113-130.

Kolata, Gina Bari. 1978. "Singing Styles and Human Cultures: How are They Related?" Science CC/4339 (April 1978): 287-288.

Kongas-Maranda, Elli. 1970. "Deep Significance and Surface Significance: Is Cantometrics Possible?" Semiotica 11/2 (1970): 173-184.

Kraehenbuehl, David, and Edgar Coons. 1959. "Information as a Measure of the Experience of Music," Journal of Aesthetics \&f Ant Criticism XVII/4 (June 1959): 510-522.

LaRue, Jan. 1970. "New Directions for Style Analysis," Musicologv and the Computer: Tbree Symposia, ed. by Barry S. Brook. New York: The City University of New York Press. 194-197.

Locke, David. 1981. "Cantometrics: An Approach to the Anthropology of Music," Ethnomussicology XXV/3 (1981): 527-529.

Lomax, Alan. 1962. "Song Structure and Social Structure." Etbnology I (1962): 425-451.

Lomax, Alan. 1968. Folk Song Style and culture. Washington, D.C.: American Association for the Advancement of Science.

Lomax, Alan. 1976. Cantometrics: An Approach to the Antbropology of Music. Berkeley, CA: The University of California Press.

Maser, Siegfried. 1971. Numerische Ästhetik. Neue mathematische Verfahren zur quantitativen Beschreibung und Bewertung ästhetischer Zustände, $3^{\text {rd }}$ ed. Stuttgart: Krämer.

McHose, Allen I. 1950. "Musical Research in the Definition of Bach's Contrapuntal Harmonic Style," Proceedings of the Music Teachers National Association 42 (1950): 126-150.

Meyer, Leonard B. 1957. "Meaning in Music and Information Theory." Joumal of Aesthetics \& Art Criticism, vol. XV, no. 4 (June 1957): 412-424.

Moles, Abraham A. 1956a. "Informationstheorie der Musik." Nachricbtentechniscbe Facbberichte, vol. 3 (1956): 47-55.

Moles, Abraham A. 1956b. "Informationstheorie und ästhetische Empfindung." Gravesaner Blätter VI (December 1956): 3-9.

Moles, Abraham A. 1958. Théorie de linformation et perception estbétiche. Paris: Flammarion \& $\mathrm{C}^{\mathrm{ic}}$. American edition: Information Theory and Esthetic Perception, translated by Joel E. Cohen. Urbana: University of Illinois Press, 1966.

Moles, Abraham A. 1962. "Das neue Verhältnis zwischen Musik und Mathematik," Gravesaner Blätter vol. VI (1962): 98-103.

Moles, Abraham A. 1966. Information Theory and Esthetic Perception, translated by Joel E. Cohen. Urbana: University of Illinois Press.

Moles, Abraham A. 1986. "Approche informationnelle de la perception et de la creation Musicale," International Revieu' of the Aestbetics and Sociology, of Music (Croatia) XVII/2 (December 1986): 273297. 
Nake, Frieder. 1974. Ästbetik als Informationsverarbeitung. Grundlagen und Anwendungen der Informatik: im Bereich ästhetischer Produktion und Kritik. Wien: Springer.

Neumann, P. G., and H. Schappert. "Komponieren mit elektronischen Rechenautomaten," Nacbricblentechnische Zeitschrift vill (1959): 403-407.

Oehrle. Elizabeth. 1992. "Cantometrics: An Approach to the Anthropology of Music," British Joumal of Music Education IX/1 (1992): 83-86.

Ortmann, Otto, 1937. "Interval Frequency as a Determinant of Melodic Style." Beabody, Bulletin (December): $3-10$.

Pinkerton, Richard C. 1956. "Information Theory and Melody." Scientific America 194/2 (Febuary 1956): 7786.

Reckziegel, Walter. 1967a. Theorien zur Formalanalyse mebrstimmiger Musik. Köln: Westdeutscher Verlag.

Reckziegel, Walter. 1967b. "Musikanalyse - eine exakte Wissenschaft?" Elektronische Datenverarbeitung in der Musikwissenschaft, ed. by Harald Heckmann. Regensburg: Bosse, 203-224.

Reckziegel, Walter. 1967c. "Musikanalyse und Wissenschaft." Studia Musicologica Academiae Scientianum Hungaricae IX (1967): 163-186.

Schillinger, Joseph. 1948. The Mathematical Basis of the Arts. New York: Philosophical Library.

Schüler, Nico. 1996. "Methoden computerunterstützter Musikanalyse - ein historischer Überblick," Zum Problem und zu Metboden von Musikanalyse, ed. by N. Schüler. Hamburg: von Bockel, 1996. 51-76.

Reckziegel, Walter. 2000. Methods of Computer-Assisted Music Analysis: History, Classification, and Evaluation. Ph.D. dissertation. East Lansing: Michigan State University.

Reckzicgel, Walter. 2002. "The Philosophical Rationale of Computer-Assisted Music Analysis: Information Theory and Aesthetics," Computer-Applications in Music Research: Concepts, Metbods, Results, ed. by Nico Schüler. Frankfurt: Peter Lang, 2002. pp. 19-30.

Shannon, Claude E., and W. Weaver. 1949. The Matbematical Theory of Communication. Urbana: University of Illinois Press.

Wagner, Günther. 1976. "Exaktwissenschaftliche Musikanalyse und Informationsästhetik." International Revieu of Aestbetics and Sociology of Music VII, no. 1 (1976): 63-76.

Winckel, Fritz. 1964. "Die informationstheoretische Analyse musikalischer Strukturen," Die Musikforscbung XVII/1 (1964): 1-14.

Younghlood, Joseph E. 1958. "Style as Information." Journal of Music Theory It (1958): 24-35.

Younglbood, Joseph E. 1960. Music and Language: Some Related Analytical Techniques. Ph.D. dissertation, Incli:na University. 